Developments in Russian Politics 4 
Developments titles available from Macmillan

Patrick Dunleavy, Andrew Gamble, Ian Holliday and Gillian Peele (eds)

DEVELOPMENTS IN BRITISH POLITICS 5

Peter A. Hall, Jack Hayward and Howard Machin (eds)

DEVELOPMENTS IN FRENCH POLITICS (REVISED EDITION)

Gillian Peele, Christopher Bailey, Bruce Cain and B. Guy Peters (eds) DEVELOPMENTS IN AMERICAN POLITICS 2

Martin Rhodes, Paul Heywood and Vincent Wright (eds) DEVELOPMENTS IN WEST EUROPEAN POLITICS

Gordon Smith, William E. Paterson and Stephen Padgett (eds) DEVELOPMENTS IN GERMAN POLITICS 2

Stephen White, Judy Batt and Paul G. Lewis (eds) DEVELOPMENTS IN EAST EUROPEAN POLITICS

Stephen White, Alex Pravda and Zvi Gitelman (eds) DEVELOPMENTS IN RUSSIAN POLITICS 4

If you have any comments or suggestions regarding this list or other Developments titles, please write to Steven Kennedy, Publishing Director, Macmillan Press Ltd, Houndmills, Basingstoke RG21 6XS, UK. 


\title{
Developments in Russian Politics 4
}

\author{
Edited by
}

Stephen White

Alex Pravda

Zvi Gitelman

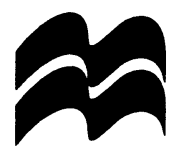


Selection and editorial matter (C) Stephen White, Alex Pravda and Zvi Gitelman 1997

Individual chapters (in order) (C) Richard Sakwa, Stephen White, John P. Willerton Jr, Thomas F. Remington, Ronald J. Hill, Matthew Wyman, Robert Sharlet, Peter Rutland, Judith Shapiro, Mary Buckley, Alex Pravda, Kathryn Stoner-Weiss, Darrell Slider, Zvi Gitelman 1997

All rights reserved. No reproduction, copy or transmission of this publication may be made without written permission.

No paragraph of this publication may be reproduced, copied or transmitted save with written permission or in accordance with the provisions of the Copyright, Designs and Patents Act 1988, or under the terms of any licence permitting limited copying issued by the Copyright Licensing Agency, 90 Tottenham Court Road, London W1P 9HE.

Any person who does any unauthorised act in relation to this publication may be liable to criminal prosecution and civil claims for damages.

The authors have asserted their rights to be identified as the authors of this work in accordance with the Copyright, Designs and Patents Act 1988.

First published (Developments in Soviet Politics) 1990

Second edition (Developments in Soviet and Post-Soviet Politics) 1992

Third edition (Developments in Russian and Post-Soviet Politics) 1994

Fourth edition (Developments in Russian Politics 4) 1997

Published by

MACMILLAN PRESS LTD

Houndmills, Basingstoke, Hampshire RG21 6XS

and London

Companies and representatives

throughout the world

ISBN 978-0-333-69470-1 ISBN 978-1-349-25852-9 (eBook)

DOI 10.1007/978-1-349-25852-9

A catalogue record for this book is available from the British Library.

This book is printed on paper suitable for recycling and made from fully managed and sustained forest sources.

$\begin{array}{rrrrrrrrrr}10 & 9 & 8 & 7 & 6 & 5 & 4 & 3 & 2 & 1\end{array}$

$\begin{array}{llllllllll}06 & 05 & 04 & 03 & 02 & 01 & 00 & 99 & 98 & 97\end{array}$

Copy-edited and typeset by Povey-Edmondson

Tavistock and Rochdale, England 


\section{Contents}

List of Figures, Maps and Tables viii

Preface $\quad \mathrm{x}$

Notes on the Contributors $\quad \mathrm{xi}$

List of Abbreviations $\quad \mathrm{xV}$

Glossary of Terms $\quad$ xvi

1 From the USSR to Postcommunist Russia 1

Richard Sakwa

The Flawed Beginning 2

Features of Communist Rule 5

Patterns of Communist Rule $\quad 11$

The Fall of Soviet Power $\quad 13$

2 From Communism to Democracy? 19

Stephen White

Reforming Communism $\quad 20$

Constructing Postcommunism 28

Part One: The Russian Political System

3 Presidential Power John P. Willerton Jr 35

The Strong Executive and Political Past 39

The Political Executive and the Transition Period 41

Institutions of the Hegemonic Presidency 45

Regime Norms and the Changing Yeltsin Coalition 51

Yeltsin's Second Term

4 From Soviets to Parliamentarism 61

Thomas $F$. Remington

Reform and the Transition Period 63

Parties and the Parliamentary Process 75 
5 Parties and Public Organisations Ronald J. Hill 82 The Legacy of the CPSU $\quad 82$

Parties and Democracy $\quad 84$

Challenges to the Communist Monopoly 88

A Plethora of Parties $\quad 89$

Parties in the New Power Framework 91

Parties in the 1995 Duma Election 93

Party Identity and Membership $\quad 98$

Associations and Groups 101

$\begin{array}{ll}\text { Conclusion } & 103\end{array}$

6 Elections and Voting Behaviour Matthew Wyman 104

The Electoral Process in Postcommunist Russia 105

Electoral Dynamics, 1993-6 109

Electoral Participation 118

The Social Basis of Voting $\quad 119$

Regional Voting Patterns 123

Conclusion: The Function of Elections in the New $\begin{array}{ll}\text { Russia } & 128\end{array}$

7 The Progress of Human Rights Robert Sharlet 129

Gorbachev's Legacy 129

The Importance of Rights in Russia 131

What the Russian Constitution Says: Human Rights in Theory 134

Russia's Progress: Hopes and Difficulties 139

Conclusion $\quad 145$

\section{Part Two: The Policy Process}

8 The Rocky Road from Plan to Market Peter Rutland 149 The Soviet Economic System 151

The Strategy of Postcommunist Reform 156

Assessing Postcommunist Reform 164

$\begin{array}{ll}\text { Conclusion } & 168\end{array}$

9 Health and Health Care Policy Judith Shapiro 169

$\begin{array}{ll}\text { The Legacy } & 170\end{array}$

1992: Maturing Crisis 176

Debates and Prospects 184

$\begin{array}{ll}\text { Soft States and Soft Social Policies } & 187\end{array}$ 
10 Women and Public Life Mary Buckley 189

Women in the Soviet Past

Women and Work in the 1990s

Women and Politics

Women of Russia in the Duma

Women Activists outside the Duma

203

Conclusion

11 The Politics of Foreign Policy Alex Pravda 208

Political Debate

Elections

Parliament

218

Executive Politics

Part Three: Political Issues in Postcommunist Russia

12 Federalism and Regionalism

Kathryn Stoner-Weiss

The Problematic Legacy of the Soviet System

Democratisation, Marketisation and the Devolution of Power, 1990-6

The Ongoing Challenges to the Development of Russian Federalism

13 Regional and Local Politics Darrell Slider

The Institutional Framework

Executive Powers at the Local Level

258

Conclusion

265

14 The Democratisation of Russia in Comparative

Perspective Zvi Gitelman

What is Democracy?

Transition, Democratisation and Consolidation 268

The Prospects for Democracy in Russia 269

Democratisation in Russia in Comparative Perspective 273

Guide to Further Reading 


\section{List of Figures, Maps and Tables}

Figures

2.1 Satisfaction with the market economy, the direction Russia is taking, human rights performance and the development of democracy, 1990-6

9.1 Mortality of work-age men in Russia, 1959-94

Maps

6.1 Vote for Yeltsin in the 1996 presidential elections, round one

6.1 Vote for Zyuganov in the 1996 presidential elections, round one

6.3 Nationalist vote in the 1996 presidential elections, round one

\section{Tables}

3.1 Leading strategists of economic policy during Yeltsin's first term, 1991-6

3.2 The 1996 Russian presidential election

3.3 Leading members of Yeltsin's second term government, January 1997

4.1 Political factions in the State Duma, April 1994

4.2 Party factions in the State Duma, 16 January 1996

4.3 Leadership posts in the Second Duma, by faction, January 1996

5.1 The range of Russian parties and electoral blocs, $1995 \quad 96$

6.1 Greatest social problems: survey results, 1991-6

6.2 Russian parliamentary and presidential elections, 1993-6 
6.3 1996 presidential election: movement of votes between the two rounds

6.4 Voting trends, 1993-5

8.1 Soviet economic performance 1971-88 153

8.2 Russian economic performance 1991-6 165

9.1 Russian life expectancy at birth 177

9.2 Alcohol consumption, Russia 1981-93 181

9.3 Proportion of GDP spent on health care, 1990-5 182

9.4 Spending on health care in constant ruble prices, 1990-4 183

10.1 Seats in the Duma from the party list, 1995 election 197

10.2 Political affiliation of women elected to the Duma in the single-member constituencies, 1995 election

12.1 Russia's republics and regions (according to the 1993 Constitution)

13.1 Background of Russian regional leaders, January $1997 \quad 258$ 


\section{Preface}

This is a book that has gone through three new editions and three changes of title, It began as developments 'in Soviet politics'; it became developments 'in Soviet and post-Soviet politics' in 1992; and in our third edition in 1994 it changed again to 'Russian and post-Soviet politics'. This fourth edition, as its title suggests, is concerned with Russian politics alone, not with those of the former Soviet republics; and it places its emphasis squarely upon postcommunist Russia, and upon the system that has developed since the end of the USSR in 1991. We hope, at the same time, not to have lost a longer perspective of which Russians are themselves very aware: not just of seventy years of communist rule, but of attempts over many centuries to limit the powers of the state and strengthen those of ordinary citizens. The establishment of a postcommunist system has, in this sense, been another 'revolution from above'; and the chapters in this book take a cautious view about the extent to which it has represented a transition not just from communist rule but $t o$ a form of government that gives Russians, for the first time, a real degree of influence over the leaders that speak in their name.

The editors would like to acknowledge the assistance in preparing the maps that was provided by Sarah Oates, and the skill with which the final manuscript was generated electronically by Jeanette Berrie. Most of all, we would like to thank our contributors, in different countries and continents, for their commitment to this project, and our publisher, Steven Kennedy, for his close and constructive interest in a succession of draft chapters as well as in the overall design. Several chapters and contributors are new to this edition, and all the other chapters have been entirely rewritten; our aim, as before, is to concentrate upon patterns of change rather than minor detail, and to emphasise the issues of interpretation to which they give rise. We hope that not just our students, but a wider circle of scholars and members of the general public, will find that this new and very different edition will justify the considerable effort that has been invested in it.

Stephen White Alex Pravda Zvi Gitelman 


\section{Notes on the Contributors}

Mary Buckley is Reader in Politics at the University of Edinburgh. Her books include Women and Ideology in the Soviet Union (1989), Redefining Russian Society and Polity (1993), Perestroika and Soviet Women (edited, 1992) and, more recently, Post-Soviet Women: from the Baltic to Central Asia (edited, 1997). In 1995/96 she was recipient of an ESRC research grant to work on rural stakhanovism of the 1930s.

Zvi Gitelman is Professor of Political Science and Preston Tisch Professor of Judaic Studies at the University of Michigan, Ann Arbor, where he is director of the Frankel Center for Judaic Studies. Author or editor of eight books, he is editor of Bitter Legacy: Confronting the Holocaust in the USSR (1997). He is currently researching the meanings of Jewish identity and communal reconstruction in Russia and Ukraine.

Ronald J. Hill is Professor of Comparative Government and Fellow of Trinity College, Dublin. His recent publications include The Soviet Communist Party (with Peter Frank, 3rd edn, 1987), Restructuring Eastern Europe: Towards a New European Order (coedited, 1990) and Beyond Stalinism: Communist Political Evolution (edited, 1992). He is also a managing editor of the Journal of Communist Studies and Transition Politics and general editor of a monograph series, Studies of Communism in Transition.

Alex Pravda is Director of the Russian and East European Centre and Fellow of St Antony's College, Oxford University, where he is also Lecturer in Russian and East European Politics. His books include The End of the Outer Empire: Soviet-East European Relations in Transition (edited, 1992) and Internal Factors in Russian Foreign Policy (with Neil Malcolm, Roy Allison and Margot Light, 1996).

Thomas F. Remington is Professor of Political Science at Emory University, Atlanta. He has written a number of articles and books on Russian and Soviet politics. His books include The Truth of Authority: Ideology and Communication in the Soviet Union (1988); Politics and the Soviet System (edited, 1989); and Parliaments in Transition (edited, 1994). He is associate editor of Russian Review. 
Peter Rutland is Associate Professor of Department of Government at Wesleyan University, Connecticut. He is author of The Myth of the Plan (1985), The Politics of Economic Stagnation in the Soviet Union (1992), and of a forthcoming study, Russia, Eurasia and the Global Economy.

Richard Sakwa is Professor of Russian and European Politics at the University of Kent, Canterbury. His recent publications include Soviet Communists in Power (1987), Gorbachev and his Reforms (1990), and a second edition of Russian Politics and Society (1996). $\mathrm{He}$ is also a member of the editorial board of the Journal of Communist Studies and Transition Politics.

Judith Shapiro is Senior Lecturer in Economics at Goldsmiths College, University of London, and is currently also an advisor with the Russian-European Centre for Economic Policy in Moscow, where she has been living or commuting since 1993. Her recent publications include Transformation and Integration: Shaping the Future of Central and Eastern Europe (with others, 1994) and a series of papers on Russian mortality and socioeconomic trends.

Robert Sharlet is Chauncey Winters Professor of Political Science at Union College in Schenectady, New York, and a member of the Professional Advisory Board of the Harriman Institute of Columbia University. During 1994-6, he worked on legal reform in the post-Soviet states as Senior Coordinator of the Rule of Law Consortium of Washington, DC. He is author and editor of a number of books and numerous articles on Soviet and Russian law and politics, including Soviet Constitutional Crisis (1992).

Darrell Slider is Professor of Government and International Affairs at the University of South Florida, Tampa. His publications include The Politics of Transition: Shaping a Post-Soviet Future (with others, 1993) and a series of papers on regional issues, public opinion, elections and privatisation in Soviet Studies, Slavic Review, Post-Soviet Affairs and other professional journals and symposia.

Kathryn Stoner-Weiss is Assistant Professor of Politics and International Affairs at Princeton University. She is the author of Local Heroes: The Political Economy of Russian Regional Governance 
(1997), and is currently engaged in research on Russian federalism and the impact of demands for subnational autonomy on state integration. She holds a PhD in Government from Harvard University.

Stephen White is Professor of Politics at the University of Glasgow, and was President of the British Association for Slavonic and East European Studies in 1994-7. He is chief editor of the Journal of Communist Studies and Transition Politics and general editor of the Cambridge Russian, Soviet and Post-Soviet monographs series; his recent publications include Russia Goes Dry (1996) and How Russia Votes (with Richard Rose and Ian McAllister, 1997).

John P. Willerton is an Associate Professor of Political Science at the University of Arizona, Tucson. His articles have appeared in Slavic Review, Soviet Studies, Studies in Comparative Communism, International Politics and other journals and professional symposia. A specialist on Russian and post-Soviet elite politics and the policy process, he is the author of Patronage and Politics in the USSR (1992).

Matthew Wyman is Lecturer in Politics at the University of Keele. His study of Public Opinion in Post-Communist Russia appeared in 1997, and he has also authored or coauthored papers in EuropeAsia Studies, the Journal of Communist Studies and Transition Politics, Electoral Studies and Party Politics. 


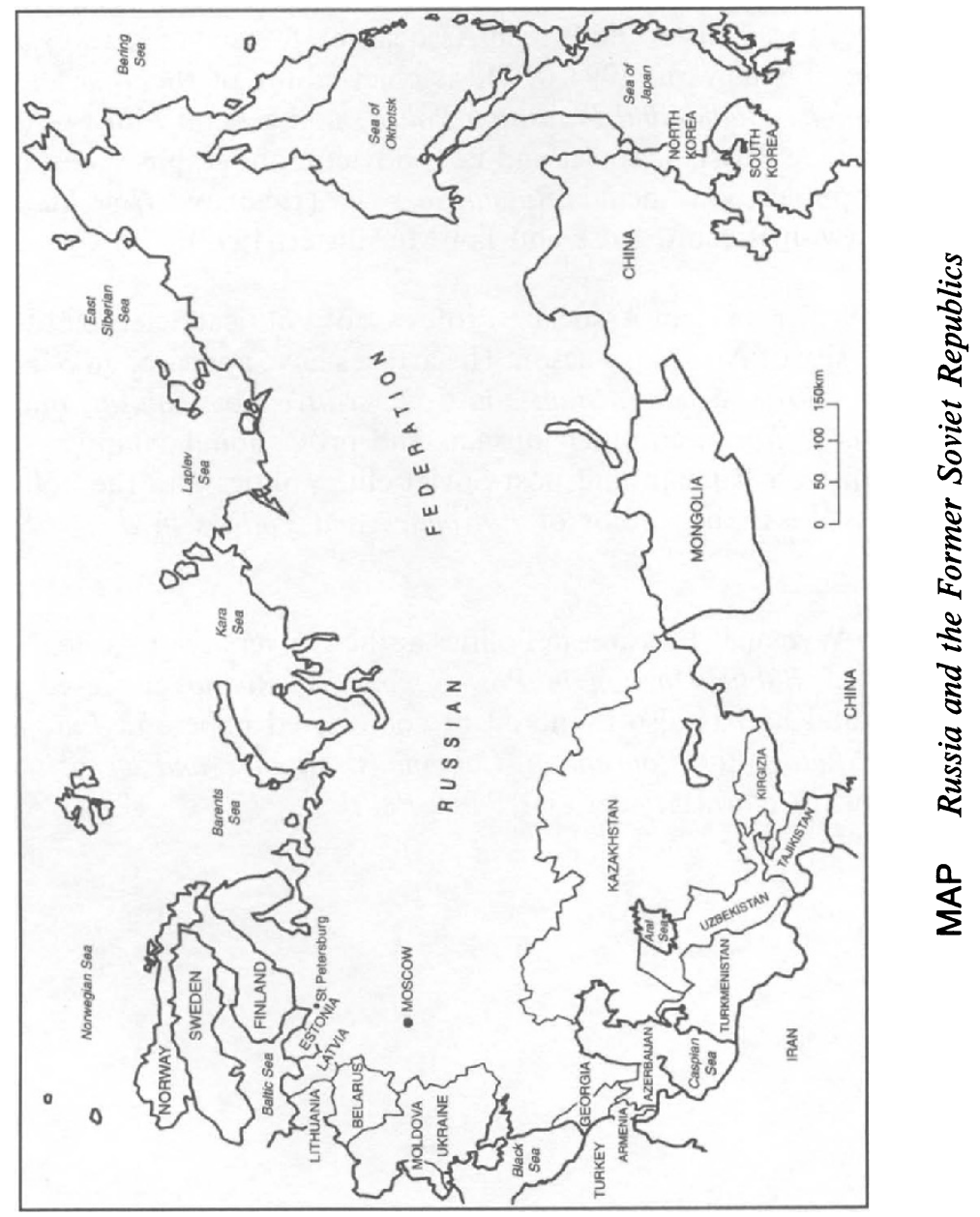




\section{List of Abbreviations}

$\begin{array}{ll}\text { APR } & \text { Agrarian Party of Russia } \\ \text { ASSRs } & \text { Autonomous Soviet Socialist Republics } \\ \text { CC } & \text { Central Committee } \\ \text { CIS } & \text { Commonwealth of Independent States } \\ \text { CPE } & \text { Centrally Planned Economy } \\ \text { CPRF } & \text { Communist Party of the Russian Federation } \\ \text { CPSU } & \text { Communist Party of the Soviet Union } \\ \text { CSCE } & \text { Commission on Security and Cooperation in Europe } \\ \text { GKI } & \text { State Property Committee } \\ \text { GNP } & \text { Gross National Product } \\ \text { KRO } & \text { Congress of Russian Communities } \\ \text { LDPR } & \text { Liberal Democratic Party of Russia } \\ \text { NEP } & \text { New Economic Policy (1921-8) } \\ \text { NEZDHI } & \text { Independent Women's Democratic Initiative } \\ \text { NPUR } & \text { National Patriotic Union of Russia } \\ \text { OHIR } & \text { Our Home is Russia party } \\ \text { PR } & \text { Proportional Representation } \\ \text { RC } & \text { Russia's Choice party } \\ \text { RCB } & \text { Russian Central Bank } \\ \text { RDC } & \text { Russia's Democratic Choice party } \\ \text { RSFSR } & \text { Russian Soviet Federated Socialist Republic } \\ \text { SAFO } & \text { Free Association of Feminist Organisations } \\ \text { SWC } & \text { Soviet Women's Committee } \\ \text { USSR } & \text { Union of Soviet Socialist Republics } \\ \text { Yabloko } & \text { Yavlinsky-Boldyrev-Lukin bloc (party) } \\ & \end{array}$




\section{Glossary of Terms}

$\begin{array}{ll}\text { Apparat } & \text { Party administrative apparatus } \\ \text { Apparatchik } & \text { Full-time party official } \\ \text { Bolshevik } & \text { Radical ('majority') faction of Russian Social } \\ & \text { Democratic Labour (later Communist) Party } \\ \text { Duma } & \text { Lower house of Federal Assembly (parliament) } \\ \text { Glasnost } & \text { Openness, publicity } \\ \text { Goskomstat } & \text { State Statistics Committee } \\ \text { Kolkhozy } & \text { Collective farms } \\ \text { Komsomol } & \text { Young Communist League } \\ \text { Krai } & \text { Territory } \\ \text { Kulaks } & \text { Rich peasants } \\ \text { Magnitizdat } & \text { Underground literature - circulation of words } \\ & \text { and songs on audio tape } \\ \text { Nomenklatura } & \text { List of party-controlled posts } \\ \text { Obkom } & \text { Regional CPSU committee } \\ \text { Oblast } & \text { Region, province } \\ \text { Perestroika } & \text { Restructuring } \\ \text { Plenum } & \text { Full (plenary) meeting } \\ \text { Politburo } & \text { Key decision-making body in the Communist } \\ & \text { Party } \\ \text { Postanovleniya } & \text { Resolutions } \\ \text { Razdel produktsii } & \text { Production sharing } \\ \text { Reglament } & \text { Standing orders (of the State Duma) } \\ \text { Samizdat } & \text { Underground literature - self-publication } \\ \text { Soviets } & \text { Councils } \\ \text { Tamizdat } & \text { Underground literature - publishing abroad } \\ \text { Ustavy } & \text { Statutes } \\ \text { Zastoi } & \text { Stagnation } \\ \text { Zemskii sobor } & \text { Assembly of nobility, clergy and merchants } \\ \text { Zemstvo } & \text { Local representative assembly } \\ \text { Zhensovety } & \text { Women's councils } \\ & \end{array}$

